\title{
KRING RIKSUTSTÄLLNINGARS SEMINARIER OCH EKOMUSEIBEGREPPET
}

\author{
Ulla Keding Olofsson
}

När jag pensionerades hösten 1995 efter 28 år på Riksutställningar erbjöds jag ett avslutande "önskeseminarium» - kring valfritt ämne.

Jag tänkte då tillbaka på alla människor och ämnen som passerat revy $i$ de seminarier som arrangerats sedan 1970-talet $i$ samarbete med kolleger inom och utom

Riksutställningar. Det har varit ämnen som utställningsform, konstnärers och arkitekters medverkan i utställningsarbete, barnverkstäder, arbetsplatsmuseer, forskningsinformation, samarbete med folkbildningsorganisationer, Riksutställningars roll $i$ konstlivet och svensk kulturpolitik och inte minst regelbundet aterkommande rapporter från andra länders utställningsliv. Medverkande har varit både medarbetare vid Riksutställningar, svenska kolleger från olika verksamhetsområden och intressanta personligheter från andra länder som Kanada, USA, Frankrike, Storbritannien, Belgien, Tyskland, Danmark, Pakistan.

Snart utkristalliserade sig ett ämne som jag under många år hade tillfälle att följa på nära håll, ett ämne och ett begrepp som fortfarande är aktuellt och under utveckling, nämligen ekomuseibegreppet. Jag började skissa på uppläggning och medverkande, fick klartecken från Riksutställningars ledning och kontaktade olika personer. Det visade sig att jag råkat pricka in ett dubbeljubileum - ekomuseibegreppets 25 år och Ekomuseum Bergslagens 10 år! Därmed kunde detta seminarium i god Riksutställningstradition också bli ett samarrangemang - i detta fall med Ekomuseum Bergslagen.

När jag började på Riksutställningar 1967 blev min första uppgift att undersöka museernas pedagogiska arbete och utveckla försöken med utställningen som läromedel. I samband med ett arbetssammanträde i Strasbourg, på Europarådet, där en bok om museipedagogik förbereddes, fick jag höra att en Unesco-anknuten organisation, ICOM, museernas internationella organisation, förberedde en stor konferens om museernas roll $\mathrm{i}$ undervisningen 
4 våren 1968 i Sovjetunionen. ICOM hade vid denna tid ganska få medlemmar i Sverige, främst museichefer. Genom att en av dessa chefer fick förhinder i sista stund, lyckades jag få medverka och informerade då om den pågående svenska museiutredningen (MUS 65) och Riksutställningars försöksverksamhet, bl.a. på skolområdet.

Denna ICOM-konferens med 81 deltagare från 18 länder gav en mycket god inblick $\mathrm{i}$ hur museernas undervisningsverksamhet såg ut i olika delar av världen. I min rapport, som publicerades av Skolöverstyrelsen (PM från SÖ 1969:2) beskrev jag bl.a. den uppsökande verksamhet med museibussar, som bedrevs i Nigeria och Indien. Jag såg en intressant tendens i museernas växande samarbete med grupper utanför museerna - lärare, sociologer, psykologer, massmedia. I konferensen deltog ICOMs tidigare direktör, Georges Henri Rivière och och den dåvarande Hugues de Varine. Den senare betonade särskilt att museernas användbarhet i undervisningen kunde bli deras räddning i framtiden, särskilt i många unga stater. Det gällde att få myndigheterna att inse att museer var en samhällelig nödvändighet.

ICOMs vart tredje år återkommande generalkonferens hölls 1971 i Frankrike på temat "Museet i människans tjänst idag och i morgon. Museets roll för undervisning och kultur" ("The museum in the service of man today and tomorrow» ICOM 1972). Jag blev ombedd att fungera som koordinator, dvs. hålla kontakt med alla föredragshållare före och under konferensen samt skriva en sammanfattning. Denna konferens, som hölls i Paris och Grenoble, blev minnesvärd, med häftiga diskussioner både kring ICOMs arbetsformer och brist på demokrati och kring inledarnas föredrag. Bo Lagercrantz refererade i Dagens Nyheter under rubriken Svarta museer och vita:

Filosofiprofessorn Stanislas Adotevi från Dahomey hatar museer och vill minst av allt grunda nya sådana. Museerna är till för att hålla de gamla myterna vid liv. --- Man påstår sig vilja bilda människorna men håller dem i stället borta från dagens problem. --- De breda lagren, som hittills ignorerats av museimännen, måste ges andra modeller än den klassiska antiken och renässansen. Dessa modeller har Frankrike redan i sina kulturhus. Sådana dynamiska centra för folkbildningen och en aktiv kommunikation människorna emellan vill man ha även i Afrika.

Bo Lagercrantz refererar också en annan av debattörerna, afro-amerikanen John Kinard, chef för Anacostia Neighbourhood Museum i Washington:

Museet kan endast fungera i den mån det ägnar sig åt människans villkor idag och i morgon. Kinard har redan förverkligat morgondagens grannskapscenter i Anacostias folkrika negerslum i Washington. Där bor några hundra tusen svarta och tre gånger så många råttor. RATS blev därmed ämnet för Kinards mest uppmärksammade utställning hittills.

Det var under denna konferens, där det traditionella museibegreppet ifrågasattes, som termen ekomuseum hördes första gången offentligt. Det var när den franske miljöministern Poujade hälsade alla konferensdeltagare välkomna till Dijon, där vi stannade för lunch under en tågresa från Paris till Grenoble. Ordet "ekomuseum» hade några månader tidigare skapats av Hugues de Varine.

Ett första exempel på vad ett sådant eko- 
museum skulle kunna innebära började växa fram i västra Frankrike, nära vindistrikten i Bourgogne, i kommunen Le Creusot-Montceau-les-Mines. Det beskrevs i Unescos tidskrift Museum (1973:4) av Hugues de Varine som $A$ 'fragmented' museum - ett fragmentariserat museum, ett experiment, ett helt nytt museibegrepp. Museeet skapades med aktiv hjälp från lokalbefolkningen och var avsett för dem. Begreppet blev mycket omdiskuterat redan från början. Avsikten var att det kontinuerligt skulle utvecklas. Rivière gav det ständigt en provisorisk definition, une définition évolutive.

I samband med arbetet inom ICOM fick jag i mars 1974 möjlighet att besöka Le Creusot. I min rapport fäster jag mig särskilt vid att lokala grupper gjort egna utställningar i alla tänkbara lokaler. Jag slogs av likheten med Riksutställningars projekt Cirklar gör egna utställningar och regionala verksamhet uppe i Skellefteområdet. Jag återsåg också med glädje material från Riksutställningar. En mexikansk praktikant i Le Creusot, Yolanda Ramos Galicia, hade gjort ett studiebesök hos oss i Stockholm och fătt med sig idéer och material, bl.a. lådutställningarna Antikens kök och Vår kultur, samt några satser utställningsskärmar. Museets chef Marcel Evrard var intresserad av fortsatt samarbete med Riksutställningar.

Intresset för ICOM växte i Sverige under dessa år, särskilt för det utvecklingsarbete som bedrevs inom kommittén för undervisning och utåtriktad verksamhet, Ceca. I september 1976 hölls en stor internationell konferens i Västerbotten på inbjudan av länsmuseet i Umeå och IcomCeca, vars sekretariat denna period sköttes av Riksutställningar. Temat var Museets roller $i$ en decentraliserad kulturpolitik. Inledningsanföranden hölls av bl.a. utbildningsminister Bertil Zachrisson, ICOMs generalsekreterare Luis Monreal och dåvarande landsantikvarien Per-Uno Ågren.

Syftet med konferensen var dels att genom en rundresa i länet ge så konkreta upplevelser som möjligt av det lokala och regionala arbete som bedrevs inom Västerbotten i samarbete med skolor, folkbildning, hembygdsrörelse och andra kulturorganisationer, dels att låta inbjudna föreläsare ge ytterligare exempel från olika håll i världen på förnyelse av regionalt och lokalt museisamarbete. Exempel gavs från Mexiko, Nigeria, Norge, Iran, Östtyskland och Sverige, med presentation av Riksutställningars uppsökande verksamhet och utställningen Industriarbetarnas historia $i$ Hallstahammar. Slutligen presenterades exemplet Le Creusot av Hugues de Varine, The museum in the fourth dimension. Erfarenheterna från denna konferens spreds vidare dels genom en samling miniaffischer, som deltagarna utformat gruppvis, dels genom artiklar i Svenska Museer (1976:2), Unescos Museum (1976:4) och Icom-Cecas tidskrift Icom-Education (1977/78).

För att utnyttja närvaron av alla museipersonligheter, som passerade Stockholm på väg till Umeå, inbjöd Riksutställningar till ett seminarium, om bl.a. ekomuseibegreppet, The Non-Exhibition, med Hugues de Varine som inledare. För dem som stannade några dagar efter konferensen i Västerbotten erbjöd Riksutställningar möjligheten att lyssna på Kenneth Hudson, som presenterade sin nya, ännu ej utkomna bok, Museums for the 1980's. A survey of world trends, med förord av Georges Henri Rivière. I denna bok, som skrevs på uppdrag av Unesco, ger författaren ett 
afrikanskt exempel på begreppet ekomuseum, nämligen Bagamoyo i Tanzania.

1976 var också det år då Kenneth Hudson med stöd av Europarådet och ICOM startade EMYA - det europeiska museipriset. Priser och hedersomnämnanden ges till nya museer, som visar samhällsansvar och pionjäranda, för att medverka till större publicitet kring museiaktiviteter. Alla museer som anmäler sig som kandidater till priset presenteras varje år $\mathrm{i}$ en illustrerad broschyr på engelska och franska.

Priset delades ut första gången 1977 och gick då till Ironbridge Gorge Museum, a remarkable open air museum of industrial archaeology, with many historic monuments in its care. Som ledamot av prisjuryn besöke jag museet och skrev en kort rapport senare, för information till alla intresserade. Vissa paralleller med Le Creusot kunde dras, men olikheterna var stora, och termen ekomuseum användes inte heller för Ironbridge.

De egentliga ekomuseerna kom att uppmärksammas en hel del i fortsättningen i samband med museipriset. År 1978 fick Le Creusot hedersomnämnande och 1979 gick förstapriset till ekomuseet i Camargue utanför Arles i Sydfrankrike. Riksutställningar gav då ut en fyllig, illustrerad dokumentation för att informera svenska kolleger om detta nya ekomuseum.

Samtidigt var vi många som med intresse och ibland viss undran följde utvecklingen i Le Creusot. Jag fick tillfälle att göra ett återbesök där i mars 1979 och konstaterar i min rapport att

Marcel Evrard föreföll ha kluvna känslor inför alla de framgångar han mött. Det kan ha sina problem att plötsligt finna sig arbeta i medvind, när man vant sig vid motsatsen.
Jag såg då också en vandringsutställning som Eva Persson, tjänstledig från Riksutställningar, gjort för ekomuseet. Hon beskrev sina erfarenheter i artikeln Allas museum (Form 1978:8): «I Le Creusot förstår jag att jag tillhör en föråldrad museigeneration». Texten kompletterad med bl.a. kartor sammanställdes på Riksutställningar till ett informationshäfte, som sändes ut till olika intressenter. I en efterskrift refererar Eva Persson en diskussion med tjänstemän i Le Creusot, som kom henne att undra: "Vart är Ekomuseet på väg?»

Det internationella intresset för ekomuseet i Le Creusot var stort och studiebesöken, inte minst från Sverige, var täta. När Franska institutet i Stockholm, som under några år hade en mycket aktiv ledning, sökte samarbete med Riksutställningar, föll det sig därför naturligt att arrangera ett seminarium (som alltid öppet för alla intresserade) kring Le Creusot. Mathilde Scalbert, biträdande chef för Le Creusot, inbjöds att tala om Museet utan samlingar - erfarenheter fràn Ecomusée Le Creusot, i april 1983.

Våren 1984 publicerades rapporten Ekomuseum Västerbergslagen av Dalarnas museum, och därmed dokumenterades att ekomuseitankarna slagit rot i Sverige som en vidareutveckling av friluftsmuseibegreppet. Förebilderna Ironbridge Gorge och Le Creusot beskrivs i denna rapport som bakgrund till det förslag om en utveckling av den regionala verksamheten som rapporten för fram. Där framgår att Mathilde Scalbert besökt tänkta objekt i Västerbergslagen och rapporten föreslår fortsatta täta kontakter för erfarenhetsutbyte med Le Creusot.

Det planerade ekomuseet såg också möj- 
ligheterna till samarbete med Riksutställningar. Mars 1983 invigdes en vandringsutställning Johan Ablbäck - arbetets målare, producerad av Dalarnas museum och Riksutställningar. Utställningen, som visades på 26 platser i Sverige, kom sedan att placeras i Ahlbäckssalen på Smedjebackens bibliotek.

När slutligen Ekomuseum Bergslagen öppnades 1986, var det utvidgat från två till sju kommuner i Dalarna och Västmanland. Som kandidat till det europeiska museipriset - EMYA - 1989 presenterades museet på följande sätt av Kenneth Hudson:

The Bergslagen Ecomuseum, embracing a large and beautiful area of central Sweden, takes off roughly where the illfated but extremely important experiment at Le Creusot in France ended. The idea that a whole region can be presented as an industrial museum is full of interesting possibilities and Bergslagen has made full use of its opportunities.

Det var många starka kandidater detta år, däribland fem svenska, och första pris gick till Sundsvalls museum. Ekomuseum Bergslagen fick ett hedersomnämnande.

Och ekomuseibegreppet har fortsatt att utvecklas, inte minst i Bergslagen. Det har hållits en serie seminarier $\mathrm{i}$ Bergslagen, med föreläsare från olika håll i världen, där ekomuseitankarna analyserats. Den som en gång präglade ordet, Hugues de Varine, medverkade t.ex. sommaren 1994 och talade om Arvet - en källa till en lokalt forankrad och lokalt forvaltad utveckling och han säger sig numera föredra att använda termen Community museum samhällsmuseum - i stället för ekomuseum.

Avsikten med tvådagarsseminariet From
Burgundy to Bergslagen var att diskutera denna utveckling och allt vad den kan innebära för framtiden.

NOT

The paper was written as an introduction to the seminar From Burgundy to Bergslagen, the Growth and Development of the Ecomuseum Concept during 25 Years, May 30-31,1996. The seminar is fully covered in Riksutställningar, 1996/3.

\section{SUMMARY}

The international development of the ecomuseum concept as reflected by Riksutställningar.

Ulla Keding Olofsson who had served Riksutställningar for 23 years from the very start of the institute, was granted the opportunity to organise a seminar according to her own wishes when she retired in 1965. Before then she had been responsible for the series of international seminars which had taken place at Riksutställningar in Stockholm from 1973 and onwards. A complete list of the seminars and topics is added to the text which she herself offered as an introduction to the seminar in her honour. It took place on May 30 and 311996.

The ecomuseum concept was essentially brought to attention in Sweden through the seminars. Mrs Olofsson had attended the 1971 general conference of ICOM in Grenoble, where the word ecomuseum was introduced. She lists the occasions on which the development of the ecomuseum-movement, later called the new museology, was reflected in seminars and visits by people engaged in ecomuseum projects. Of special interest is the fact that $\mathrm{Mrs}$ Mathilde Scalbert, Vice Director of Le Creusot, was an invited guest to a seminar in 1983, where she spoke about The museum without collections - experiences of Ecomusée Le Creusot, and that in the following year the idea of a Swedish equivalent, 
Ekomuseum Bergslagen, was launched and published in the form of a report from Dalarna's Museum, Falun. This is one example of what Riksutställningar and its international seminars have meant for the introduction of innovators and new thinking into the museum field in Sweden and Scandinavia.

She also recalls how the institute worked closely with Dalarna's Museum to support and participate in the renewal of the cultural action of the museum, which was led by Erik Hofrén and Örjan Hamrin, and to make the experience known in other parts of Sweden.

There was however a long way to go before Ekomuseum Bergslagen was officially inaugurated in 1986 with seven municipalities in two counties, Dalarna and Västmanland, as partners. Thus in 1996 the ecomuseum concept celebrated its 25th anniversary and Ekomuseum Bergslagen its 10th.

The idea of the seminar was to discuss recent thinking about ecomuseums and combine it with an excursion to Bergslagen to study ongoing activities and participate in the anniversary celebrations.

\footnotetext{
Ulla Keding Olofsson joined Riksutställningar in 1967 after ten years as a teacher. She worked there in various capacities until her retirement in 1965. She has sat on the governing boards of two national museums and worked internationally in ICOM since 1968. She has also served as a member of the jury for the European Museum of the Year Award, EMYA, since 1977.

Adr: Idungatan 14, S-113 45 Stockholm

Fax +46-8-344059
}

\section{RIKSUTSTÄLLNINGAR'S INTERNATIONAL SEMINARS 1973 - 1993}

Riksutställningar (The Swedish Travelling Exhibitions) has regularly organized seminars with discussions on different aspects of exhibitions and new developments in the cultural sector. For about 20 years these seminars have been organized by Ulla Keding Olofsson in co-operation with colleagues.

\section{3}

Jean Favière from France presented the ICOMCECA project Kits, small portable exhibitions.

1974

Renée Marcousé reported on projects which she was carrying out with some British museums, schools and TV: Through pleasure they create.

\section{6}

Hugues de Varine, former director of ICOM: The Non-Exhibition, with examples from Le Creusot.

Luis Monreal, secretary general of ICOM, introduced a discussion under the heading of ICOM needs us - do we need ICOM?

Kenneth Hudson, English museum consultant, introduced his forthcoming book Museums for the 1980s by speaking on Museums - the Living, the Dying and the Dead.

\section{7}

Thérèse Destrée-Heymans from Musées Royaux d'Art et d'Histoire in Brussels spoke about Museum workshops for children.

1978

We discussed The roles of ICOM's international specialized committees on the international and national levels with Paulette Olcina and Anne Raffin, the ICOM Documentation Centre in Paris.

Patrick O'Byrne, member of ICOM's International Committee for Architecture and Museum Techniques, spoke about Museum programmation.

1979

The 1978 winner of the European Museum of the Year Award, Schloss Rheydt Museum in FRG, presented by the Director Mrs Eva Briies.

Research, Exhibition and Action - Three Pillars of 
Museum Education, thesis presented by Andreas Kuntz, Diplom-Pädagog, Marburg, in co-operation with the Goethe Institut.

Museums and local population - participation and integration - A Portuguese-Swedish cultural exchange project presented by the members of the Portuguese working group Museus-UNESCO, PerUno Agren and Göran Carlsson.

1980

Randers Museum of Cultural History - a Danish provincial museum and its exhibition policy, presented by Bjorn Stïrup and Guri Dybsand.

1981

How can old buildings be adapted for museum usage? Discussion introduced by the English museum consultant Kenneth Hudson.

1982

New trends in museum exhibition design. Presentation of the candidates for the 1981 European Museum of the Year Award and discussion of the roles played by museum staff, designers, artists, educators and the public.

Designing large travelling exhibitions. Jean Dethier, architect and designer at CCI, Centre Pompidou, presented the production of the exhibition "Down to Earth - Des Architectures de terre". 1983

The Museum without collections - experiences at l'Ecomusée Creusot-Montceau-les Mines, France, presented by Mathilde Scalbert, Deputy Director. Co-operation with Institut Français.

Atelier des Enfants. Danièle Giraudy, former head of the Children's Workshop at Centre Pompidou presented the Workshop and its programme. Cooperation with Institut Français.

The Educational Service Skoletjenesten, a regional museum service for Danish schools presented by the head of the service Tage Hoyer Hansen.

\section{4}

Oral tradition and culture in Mali, presented by Alpha Oumar Konare, Vice President of ICOM, former Minister of Culture, and Birgit Akesson, Swedish choreographer and author.

Activities at the Karachi Grammar School presen- ted by Stella Jafri, headmaster, Kindergarten dept.
1985

Art Education in Canada - the Saskatchewan Experience presented by Brenda Baker. Visual Arts Coordinator, Saskatchewan Arts Councils.

\section{6}

Cultural Development in Africa. Alec Campbell, Director, The National Museum and Art Gallery of Botswana, Gaborone, on the extension of the museum, which is the largest development project within the cultural field supported by SIDA, the Swedish International Development authority.

Museum Exhibition Design - Three British Voices:

Kenneth Hudson: Honesty and dishonesty in new European museum design. In co-operation with the British Council.

Roger S. Miles, Public Services, Natural History Museum, London: Designing for the general public.

Margaret Hall, Head of Design, British Museum, introduced her new book On Display - A Design Grammar for Museum Exhibitions.

\section{7}

Kenneth Hudson introduced his new book Museums of Influence.

Italian architect Gae Aulenti interviewed by art critic Ingela Lind on her exhibition design at Musée d'Orsay in Paris and Palazzo Grassi in Venice. In co-operation with the Italian Cultural Institute.

Tomislav Sola, Director of the Museum Documentation Centre Zagreb, Yugoslavia, on National museum documentation centres - corner stones of an international network?

Pourquoi un Salon de la Muséologie? FrenchSwedish seminar at the Centre Culturel Suédois in Paris, in connection with the first "Salon de la Muséologie» (MNES), in co-operation with the Swedish National Committee of ICOM.

1988

Susanne Peters, ICOM Documentation Centre: Modern Information Technology - examples of possibilities for development and co-operation. 
ULLA Keding OlOFSSON

Words in Exhibitions, introduced by Donald Horne, Chairman of Australia Council, and Hugues de Varine, head of the French Institute, Lisbon.

1990

Le Kaléidoscope s'ouvre, an exhibition on mathematics and art, French-Swedish seminar at the Centre Culturel Suédois in Paris, with Jacques Perot, Head of the French ICOM committe, the secretary of ICEE Johanne Landry, la Villette, and the head of CSS, Carl Henrik Svenstedt.

Ph. D. Rosemary Sassoon: Handwriting in Sweden at the Lärarhögskolan in Linköping, in connection with the exhibition "Scrawls and Frills".

1991

Seminar The Art Machine with Ken Baynes, Professor in Design at Loughborough University.

1993

Beware of the anthropologies! They are making museum specimens of you (after Derek Walcott). Discussion about the ways in which we exhibit the culture of other peoples. Introduction by Jacques Hainard, Director of Musée d'Ethnographie, Neuchâtel, Switzerland, and Tsitsi Dangarembga, author from Zimbabwe. In cooperation with SIDA.

Fighting hatred of foreigners and racism in Sweden. Can exhibitions be an efficient tool? Introduction by Françoise Wasserman, Director of the Ecomuseum in Fresnes, outside Paris, as well as Swedish organizers of exhibitions and immigrants. Co-operation with Nordiska museet and The Swedish Immigration Institute.

Excellence and Equity: Education and the Public Dimension of Museums. Bonnie Pitman, Director of the University Art Museum, Berkeley, USA, introduced a discussion about the future role of museums in education. Co-operation with the Department for museology at the Umeå university.

Museums and the Electronic Highway. George F MacDonald, Director of the Canadian Museum of Civilization in Québec, Canada, spoke about the difficulties to present the growing number of museum objects in traditional exhibitions. Co-operation with Statens Historiska Museum in Stockholm. 